\title{
Lettera del Direttore responsabile
}

Dal 2019 Economia Pubblica The Italian Journal of Public Economics mostra molteplici novità: oltre ad essere presenti dei nuovi soci proprietari, Confservizi CISPEL Lombardia, Fondazione Utilitatis e Fondazione CAP, è stato introdotto anche un cambio strutturale; infatti la Rivista è stata implementata di una nuova sezione di ricerca scientifico giuridica ed una parte di aggiornamento manageriale che si affiancano allo storico studio di carattere economico.

Il n. 1/2019 ha visto la mia introduzione in qualità di Direttore Responsabile e la presentazione del nuovo comitato scientifico ed editoriale.

Il n. 2/2019 consegna ai propri lettori un'ulteriore novità, infatti questo vede la conduzione dei due nuovi Direttori Scientifici: il Prof. Antonio Massarutto, per la parte economica, e il Prof. Giovanni Cocco per la sezione giuridica.

Colgo quindi l'occasione per augurare ai nuovi Direttori Scientifici un buon lavoro, certo che sosteranno egregiamente la Rivista nel suo percorso di crescita.

Contestualmente è doveroso ringraziare il Prof. Lorenzo Robotti, che per anni ha svolto il ruolo di Direttore Scientifico con estrema professionalità.

In questi mesi abbiamo lavorato con profuso impegno per offrire un prodotto editoriale che sia degno del suo egregio passato e che, allo stesso tempo, ricerchi nuove vie di studio e approfondimento.

È altresì necessario quindi esprimere la mia gratitudine verso i soci proprietari, i sostenitori e i lettori per i quali questa Rivista nasce e si modifica perfezionandosi costantemente.

Giuseppe Viola

Direttore Responsabile

Economia Pubblica (ISSN 0390-6140, ISSNe 1972-5566) 2019, 2

DOI: 10.3280/EP2019-002001 


\section{Letter of Editor in chief}

From 2019 on, Economia Pubblica, The Italian Journal of Public Economics shows many new features: in addition to the presence of new owners, Confservizi CISPEL Lombardia, Fondazione Utilitatis and Fondazione CAP, a structural change was also introduced; in fact, the magazine has been implemented with a new section of legal scientific research and a managerial update part which is added to the historical economic study.

The n. 1/2019 contained my introduction as Editor in Chief and the presentation of the new scientific and editorial committee.

The n. 2/2019 gives its readers another new aspect, in fact this is characterized by the management of the two new Scientific Editor in Chief: Prof. Antonio Massarutto, for the economic part, and Prof. Giovanni Cocco for the legal section.

I therefore take the opportunity to wish the new Scientific Editor in Chief a good job, being certain they will support the magazine in its growth path, in an excellent way.

At the same time it is important to thank Prof. Lorenzo Robotti, who has maintained the role of Scientific Editor in Chief with extreme professionalism, for years.

In the last few months we have worked with profuse commitment to offer an editorial product that is worthy of its distinguished past and that, at the same time, seeks new sectors of study.

It is, therefore, also necessary to express my gratitude to the owners, supporters and readers thanks to whom this magazine is born, has modified and constantly perfected.

Giuseppe Viola Editor in chief

Economia Pubblica (ISSN 0390-6140, ISSNe 1972-5566) 2019, 2 